\title{
ETHICS IN THE SOCIETAL DEBATE ON GENETICALLY MODIFIED ORGANISMS: A (RE)QUEST FOR SENSE AND SENSIBILITY
}

(Accepted in revised form April 4, 2007)

\begin{abstract}
Via a historical reconstruction, this paper primarily demonstrates how the societal debate on genetically modified organisms (GMOs) gradually extended in terms of actors involved and concerns reflected. It is argued that the implementation of recombinant DNA technology out of the laboratory and into civil society entailed a "complex of concerns." In this complex, distinctions between environmental, agricultural, socio-economic, and ethical issues proved to be blurred. This fueled the confusion between the wider debate on genetic modification and the risk assessment of transgenic crops in the European Union. In this paper, the lasting skeptical and/or ambivalent attitude of Europeans towards agro-food biotechnology is interpreted as signaling an ongoing social request - and even a quest - for an evaluation of biotechnology with Sense and Sensibility. In this (re)quest, a broader-than-scientific dimension is sought for that allows addressing the GMO debate in a more "sensible" way, whilst making "sense" of the different stances taken in it. Here, the restyling of the European regulatory frame on transgenic agro-food products and of science communication models are discussed and taken to be indicative of the (re)quest to move from a merely scientific evaluation and risk-based policy towards a socially more robust evaluation that takes the "non-scientific" concerns at stake in the GMO debate seriously.
\end{abstract}

KEY WORDS: Asilomar, genetically modified organisms, public engagement initiatives, regulatory frame, risks, science communication, societal concerns, technology assessment, values

\section{GENETICALLY MODIFIED ORGANISMS: A SOCIETAL DEBATE BETWEEN SENSE AND SENSIBILITY}

The societal debate about genetically modified organisms (GMOs) has a history of more than three decades. Initially, in the early seventies, scientists evaluated mainly the riskiness of the then newly developed recombinant DNA (r-DNA) technique that allowed the development of GMOs. From then onwards, this internal questioning became a social debate that gradually and largely extended in scope of actors involved and concerns addressed. This extension took its most extreme form in the European 
Union (EU). Here, by 1999, a growing societal opposition towards genetically modified (GM) agro-food products contributed to the installation of a de facto moratorium on the commercialization of new GMOs, and to the implementation of one of the most stringent process-based regulatory regimes worldwide (Devos et al., 2006).

In reference to research using large cross-European focus groups, Marris (2001) concluded that "the public" generally is ambivalent about agro-food biotechnology, because it simultaneously recognizes positive and negative dimensions of this technology. Although the de facto moratorium was abandoned in 2004, at present the skeptical and/or ambivalent attitude of Europeans towards GM agro-food products still holds. This is reflected in the latest Eurobarometer survey, stating that "GM food is widely seen as not being useful, as morally unacceptable and as a risk for society" (Gaskell et al., 2006: 8). This lasting skeptical and/or ambivalent attitude can be interpreted as signaling a request - and even a quest - of society for an evaluation of agro-food biotechnology with Sense and Sensibility. In other words, it is still searched for how to establish a move from a mere scientific evaluation towards a socially more robust one, in which societal issues are addressed in a more "sensible" way, whilst making "sense" of the different stances taken in the GMO debate (Levidow and Marris, 2001; Jasanoff, 2003; Nowotny, 2003).

An important aspect lying at the basis of this (re)quest is the difference in perception of risk between scientifically trained experts and lay people (Slovic, 1987; Wynne, 2001; Savadori et al., 2004). Experts tend to describe risk on grounds of strictly scientifically determined standards, whilst lay people rely on a less stringent concept of risk. In the GMO debate, lay people widely expand the concept of risk with various concerns, such as usefulness, socio-economic impacts, freedom of choice, unnaturalness of genetic modification, respect for nature, long-term consequences, irreversibility of adverse effects, democracy, disparities between the industrialized world and the third world, uncertainties, fallibility of experts, trust and/or sustainability of agriculture (Siegrist, 2000; Marris, 2001; Lassen et al., 2002; Shaw, 2002; Verhoog et al., 2003; Cook et al., 2004; Frewer et al., 2004; Deckers, 2005; Madsen and Sandøe, 2005; Lassen and Jamison, 2006). Because "the public" is not homogenous, variation in risk perception also exists between different countries and cultures, between different individuals within countries, and within different individuals at different times and within different contexts (Frewer et al., 2004).

According to Slovic et al. (2004), in any perception of risk there is a complex interplay between two "attraction poles" of reason and emotion. While these two poles operate in parallel, they depend on each other. This 
complex interplay reminds us of Jane Austin's novel entitled Sense and Sensibility. Published in 1811, under the anonym "By a Lady," this novel describes the lives of two sisters, Marianna and Elinor. On the surface, these sisters seemingly represent two opposite poles: Marianna's emotional and romantic nature represents the cult of "Sensibility," whereas Elinor's rationality represents the cult of "Sense." However, just as much as the two sisters are next of kin, their natures/characters continually co-construct each other. The sisters thus symbolize a continuous and complex process of "giving sense to sensibility," in which simultaneously "sensibility guides the making of sense." Because of the pejorative connotation the concept of "emotion" often carries (e.g., when criticism on science is dismissed as purely "emotional"), and because of the fact that in between emotion and reasons many other concerns are at play, in this paper, the metaphorical entanglement of Sense and Sensibility is used to stress the complex interplay between the various concerns playing in the societal debate on GMOs.

Via a compact historical reconstruction, the establishment of and evolutions in this complex interplay are discussed. It is addressed (i) how r-DNA technology evolved in a dynamically changing context from laboratory science to society; (ii) how various socio-economic and ethical concerns popped up along this change, drawing new actors in the front line of the debate; (iii) how the expression and meaning of societal concerns evolved; and (iv) how scientific objectives became intertwined with extrascientific - socio-economic/commercial - objectives. Given the deep revision of the European regulatory frame on transgenic crops during the de facto moratorium, it is first investigated whether any integration of "non-scientific" concerns in the restyled legal frame succeeded in taking the (re)quest for Sense and Sensibility in risk analysis of GM agro-food products seriously. Secondly, it is discussed how a similar restyling of science communication models led from a science literacy model towards engagement initiatives.

\section{SCIENCE AND TECHNOLOGY BECOMING PUBLIC}

As argued by Ulrich Beck (1992), scientific and technological advances not only bring along unquestioned benefits, they also generate new uncertainties and failures. Because of this, and because of an ongoing complexification of what is considered a contemporary risk, scientific and technological developments have been the subject of societal controversies in various 
domains. ${ }^{1}$ These controversies are indicative of the emergence of a "reflexive modernity" whereby there is a growing awareness about the ways in which "techno-scientific progress" affects the interests and values of society, and about which risks are imposed upon society. In scaling up scientific and technological developments beyond the confined limits of the laboratory, and in testing technology as a real-world experiment, this trend has been amplified. Techno-scientific developments are entering society more directly, exposing it at large to potential dangers (Krohn and Weyer, 1994; Levidow and Carr, 2007). As such, risk debates and controversies can be viewed as an expression of contending views on how potential risks should be anticipated, controlled, and distributed, but also on how society should be organized. They can be seen as a reflection of differences in underlying values and ideals (e.g., about the sort of environment that should be protected, sustained, or created, the future of agriculture). Because risk analysis approaches that form the knowledge basis for decision-making are challenged by growing scientific uncertainties, and often fail to properly integrate societal concerns and disputed values, Beck (1992) stated that modern reflexivity will lead to a growing distrust in scientific institutions and expert systems. According to Beck (1999), public acknowledgement of scientific uncertainties in the practice of scientific and technological developments opens a space for democratization and broader societal involvement. Therefore, he and others plead for more openness, the involvement of a diversity of voices and opinions, and for inter/transdisciplinary approaches in risk analysis (Funtowicz and Ravetz, 1994; Healy, 1999; Power and McCarty, 2006; Welsh and Ervin, 2006; van der Sluijs, 2007).

As a prefiguration of what is happening today, it is instructive to mention the industrial revolution, in which the replacement of manual labor by

\footnotetext{
${ }^{1}$ During World War I, chemical developments raised public commotion due to the use of gases for military purposes. Strong criticism and public resistance arose with the application of nuclear physics for military and industrial goals (culminating in the nuclear bombing of Hiroshima and Nagasaki during World War II), and with the use of nuclear weapons as a dissuasive tool in the arms race during the Cold War. During the golden sixties, the growing societal awareness of the power, the excesses and the adverse side effects of scientific and technological advances resulted in a critical attitude towards these advances as witnessed by the ideological political and philosophical debates held on the role of science and technology in societies. In this period, the anti-war movement against Vietnam reached its culmination. Radical scientists created organizations like "Scientists and Engineers for Social and Political Action" and the journal Science for the People in 1968. They criticized the US domestic and foreign policies, connected capitalism to the new military-industrial complex, and promoted "science at the service of people" instead of "science at the service of racism, sexism or exploitations." During the Green Revolution, the productionist ideology of intensive high-input agriculture started to face criticism due to its environmental degradation and lack of sustainability. In her book Silent Spring that was published in 1962, Rachel Carson denounced the devastating and irrevocable hazards of the use of the pesticide DDT.
} 
novel machinery raised huge controversy, especially among laborers. The Luddites' actions, ${ }^{2}$ for instance, not only intended to maintain living standards and conditions of labor, but also to keep access to and negotiation power about new technologies (Schot and Rip, 1996). This illustrates that beside risks, controversies also encompass social, economic, cultural, and institutional dimensions. The fascination of creating artificial life (or of "playing God" and pushing nature beyond its limits) and the fear of its unintended and uncontrollable consequences have found a symbolical representation in the Frankenstein myth. ${ }^{3}$ Nowadays, this myth survives in various GMO discourses, reflecting Shelley's "monster" as a romantic prototype of modern biotechnology (Nielsen and Berg, 2001).

\section{RECOMBINANT DNA TECHNOLOGY IN THE 1970s}

\subsection{Recombinant DNA Technique in its Socio-economic Climate}

In general, whereas the golden sixties provided a flourishing socio-economic climate, the seventies brought economic recession and major oil crises (1973, 1979, and 1980). This led to a strong public concern about the limited availability of natural resources on earth and about employment. ${ }^{4}$ In this context, the r-DNA technique was developed (Cohen et al., 1973). The restriction enzymes of Escherichia coli, discovered by Herbert W. Boyer (Stanford University) carried the capacity to specifically cut DNA strands. At the same time, Stanley N. Cohen (University of California) developed a method to remove plasmids from bacterial cells and reinsert them in other cells. Plasmids and bacterial viruses provided vehicles (or vectors) to carry foreign DNA into living cells. The combination of these two discoveries enabled Cohen and Boyer to cut and splice DNA segments in desired configurations, and to insert them in bacterial cells. This was the starting

\footnotetext{
${ }^{2}$ The Luddites - named after their legendary leader Ned Ludd - organized various protest actions against this mechanization process in the British textile industry in the early 1800s.

${ }^{3}$ The scientist Victor Frankenstein and his creature are the central figures in the novel Frankenstein or The Modern Prometheus by Mary G. Shelley, published in 1818. The story tells how Frankenstein brings to life a sewn-up mass of organs through the use of electricity, resulting in the creation of a "monster." Being rejected by humans (and not receiving the necessary affection), the creature turns against his creator and murders his relatives. After a long pursuit between Frankenstein and his creature, Frankenstein succumbs to rage and exhaustion. Realizing that now his own life has lost all meaning the creature commits suicide.

${ }^{4}$ The Limits of Growth of D. H. Meadows, D. L. Meadows, J. R. Randers, and W. W. Behrens III, published in 1972, commissioned by the Club of Rome, pinpointed that economic growth could not indefinitely be supported due to the limited availability of natural resources on earth. This publication triggered a growing environmental awareness.
} 
point for the r-DNA era, which made it possible to cut, splice and recombine DNA of different species, and therefore overcoming the species barrier. ${ }^{5}$ This technique became known as "genetic transformation" or "genetic engineering".

\subsection{Scientists and Their Concerns at Asilomar I}

From the very start, scientists themselves, working with the r-DNA technique, assessed this technique in terms of "fears" and "possible risks." This also was the case for the r-DNA technique's forerunner: the exchange of DNA between micro-organisms without the use of restriction enzymes. In 1971, the American biochemist Paul Berg and his team (Stanford University) infected $E$. coli with tumor-inducing viruses. As $E$. coli is a common intestinal bacterium in humans, the fear was that these malign viruses would spread more easily throughout the human body, changing cells from a normal to a cancerous state. Potential laboratory hazards whilst working with tumor-inducing viruses were specifically discussed by renowned scientists such as Berg and James Watson at the Asilomar Conference (California, US) on 24 January 1973. The discussion held paid attention to the safety of the laboratory workers themselves, but also covered the safety of the community living in the close neighborhood of molecular biology laboratories. As such, "the discussion turned from consent of the laboratory worker to informed consent of the community" (Krimsky, 2005: 311).

At the "Gordon Conference on Nucleic Acids" in June 1973, the critical attitude of scientists took a more collective turn (Krimsky, 2005). Attendants generally stressed the need to assess the safety of r-DNA research (Singer and Soll, 1973). Berg was asked to lead the newly formed Committee on Recombinant DNA Molecules of the National Academy of Sciences (NAS) in order to study the matter. In July 1974, the Committee proposed to install a voluntary moratorium on certain types of experiments as long as the hazards could not be properly evaluated or be prevented (Berg et al., 1974). This call for a moratorium received media coverage, alerting members of the public and inducing the first public debates on the r-DNA technique and its applications (Hindmarsh and Gottweis, 2005). On demand of the Committee, the National Institutes of Health (NIH) established the first Recombinant DNA Advisory Committee in October 1974.

\footnotetext{
${ }^{5}$ Due to the (near) universality of the genetic code, foreign DNA pieces can be expressed in about any host organism.
} 


\subsection{Societal Concerns at Asilomar II}

The Committee also requested the NAS and the NIH to organize an international meeting of involved scientists to discuss appropriate and concrete ways to deal with the potential biohazards of r-DNA molecules and to review scientific progress in this research area. This conference took place in February 1975 and is known as "Asilomar II." Similar to Asilomar I, safety issues formed the core of the discussion. Scientists feared that "microscopic Frankensteins [sic] would sneak out of the laboratory undetected" and "would threaten public health" (Barinaga, 2000: 1584). They speculated that "normally innocuous microbes could be changed into human pathogens by introducing genes that rendered them resistant to thenavailable antibiotics, or enabled them to produce dangerous toxins, or transformed them in cancer-causing agents" (Berg and Singer, 1995: 9011). It was concluded that most r-DNA work should continue, but that appropriate safeguards in the form of physical and biological containment of the newly created organisms should be implemented. It was, for instance, strongly recommended to work with disabled bacteria that could not survive outside the laboratory (Berg et al., 1975). As such, Asilomar was "widely hailed as a landmark of social responsibility and self-governance by scientists" (Barinaga, 2000: 1584).

However, Asilomar II went beyond Asilomar I: next to "involved scientists," lawyers, members of the press and government officials attended the meeting (Berg and Singer, 1995). The inclusion of these new actors was not the initial purpose of the so-called Molecular Biology Establishment (Watson and Tooze, 1981), but aimed to compensate Science for the People's criticism (see footnote 1) on the exclusion of the public (Abels, 2005). In fact, and in contrast with Science for the People, the Molecular Biology Establishment was not eager to share its concerns with the public: they believed that scientific research would be blocked by lawyers and bioethicists who neither knew nor had a real interest in their research. Still, the "intrusion" of non-scientists definitely enlarged the discussion.

The Asilomar II recommendations were promulgated by the NIH Recombinant DNA Advisory Committee and led to the NIH "Guidelines for Research Involving r-DNA Molecules" in 1976 (Singer and Berg, 1976). To permit the involvement of the public in the establishment of $\mathrm{NIH}$ guidelines, open hearings were organized (Petsko, 2002). On the one hand, these guidelines allowed for the abandonment of the voluntary moratorium and for resuming research. They also helped to persuade the US Congress that legislative restrictions were not needed (Barinaga, 2000). On the other hand, the guidelines prohibited large scale field-testing (Krimsky, 2005). 


\section{COMMERCIALIZATION OF r-DNA BETWEEN 1976 AND 1995}

From 1976 onwards, r-DNA entered the phase of commercialization. This is related to a growing attention in Molecular Biology (before a predominantly academic and fundamental research discipline mainly financed by government), to applied science financed by private capital. The commercialization movement was set in from university laboratories towards the private work floor, stock market, and marketplace. It generated a change in attitudes and research emphases: from sole scientific values, towards the inclusion of economic values (Wright, 1986; Jasanoff, 2003; Welsh and Glenna, 2006).

\subsection{First Commercialization Wave}

During a first commercialization wave (1976-1981), research and development contracts were signed between scientific academics and universities and the private sector. Other scientists themselves became entrepreneurs and created small biotechnology companies with private capital. ${ }^{6}$ These evolutions were first observed in the pharmaceutical sector. With the advent of the first r-DNA products, ${ }^{7}$ the commercial interests in biotechnology increased. Pharmaceutical multinationals acquired shares in new biotechnology companies or initiated small in-house research on r-DNA (Wright, 1986).

In addition to these evolutions, the patenting of inventions related to the r-DNA technique entered the picture and became a source of social controversy. With the Diamond vs. Chakrabarty case ${ }^{8}$ in June 1980, living organisms engineered by man became patentable in the US. Hence, a number of pending patent applications were issued. ${ }^{9}$ With the adoption of the Bayh-Dole Act of 1980, the patenting trend went into full swing: universities, companies and non-profit organizations obtained the right and incentive to hold patents on innovations arising from federally funded

\footnotetext{
${ }^{6}$ In 1976, Boyer and the private investor Robert Swanson founded the biotechnology company Genentech, which floats on the stock market since 1980.

${ }^{7}$ In 1977, Genentech succeeded in using the r-DNA technique for producing the human hormone somatostatin in bacteria. In 1978, Genentech and the City of Hope Medical Center announced the production of recombinant human insulin.

${ }^{8}$ Ananda M. Chakrabarty developed a Pseudomonas bacterium that was constructed to degrade crude oil and that could be used in the treatment of oil contaminations. To protect his invention, Chakrabarty requested a patent on the bacterium. After a first rejection of his demand by the Patent Office Boards of Appeals, the demand was later accepted by the Court of Customs and Patent Appeals.

${ }^{9}$ The pending patent applications included one of three patents known as "the Cohen-Boyer r-DNA cloning patents." This patent was submitted in November 1974 and concerned the rDNA technique itself. It was the first major patent to be issued in biotechnology (Hughes, 2001).
} 
research (Wright, 1986; Hughes, 2001). This augmented the attractiveness of commercial biotechnology.

Since 1978 onwards, the use of transgenic organisms also started to be deregulated. Although the safety issue was still under discussion in the US, it was downplayed in favor of industrial expansion. This was supported by the government and private sector in order to maintain leadership in biotechnology (Wright, 1986; Hughes, 2001). The NIH issued less stringent guidelines for scientific research using r-DNA techniques, applying exclusively to federally funded institutions (Krimsky, 2005). For the industry, compliance to the NIH guidelines was voluntary. As such, the r-DNA experimentations were limited to minimal physical and biological confinement requirements (Abels, 2005).

\subsection{Second Commercialization Wave}

The second commercialization wave (1981-1985) relied on the relaxation of containment measures, but also on the adoption of the Economic Recovery Tax Act of 1981. This Act provided tax incentives for corporate research arrangements between universities and private sector. Commercialization now occurred in different forms and phases. (i) Next to pharmaceutical multinationals, also chemical-seed and oil multinationals invested in several biotechnology companies and funded fundamental research at universities and research institutions. They largely invested in previously initiated inhouse research on r-DNA and/or achieved the knowledge by the acquisition of biotechnology companies. Universities regarded patentable r-DNA research as a means to generate new incomes and facilitate knowledge translation. (ii) Biotechnology companies grew and raised capital through public stock offerings. (iii) New biotechnology companies were created (Wright, 1986).

Various governments recognized the potential of genetic engineering and established programs to enhance the industrial development of biotechnology. Like in the US, in Europe biotechnology was incorporated in national policies. In the UK, for instance, the Spinks report stimulated fundamental research and commercial exploitation in the early eighties. Japan declared 1981, the year of biotechnology.

The efforts made by molecular biologists to develop devices for transforming plants (e.g., investigation of the tumor-inducing bacterium Agrobacterium tumefaciens as a potential vehicle of foreign DNA into plants) began to yield rewards (Bevan et al., 1983; Fraley et al., 1983; HerreraEstrella et al., 1983). With all these advances, biotechnology became an important issue for economic competition on a national and global scale. 
Also, the commercialization wave gradually extended to the agro-food and seed sector.

\subsection{Societal Involvement: New Debates, New Developments}

The commercialization of genetic engineering worldwide generated new debates. Societal concerns regarding the safety of laboratory workers and their neighborhood were extended to environmental aspects, consumption, and employment. The fact that knowledge became a commodity for private profit raised questions about (i) the patentability of natural parts of life forms, (ii) the potential adverse impacts on the access of scientists and consumers to new developments, (iii) the hybridization between fundamental and applied research, (iv) the confidentiality of scientific results, (v) the moral positions and values of science and scientists, (vi) the credibility and autonomy of scientists, and (vii) the role of the government.

Inspired by the congressional Office of Technology Assessment (OTA), ${ }^{10}$ responsible for advising policy makers and the public on the potential impacts of new technological applications, Technology Assessment (TA) initiatives were adopted worldwide, focusing also on genetic engineering. Initially, TA played a prominent role in policy by forecasting and assessing the societal impact of genetic engineering. Later, it also initiated and orchestrated public debates to elicit larger public participation in technological decision/policy-making, and to improve learning about new technologies and their societal concerns (Genus and Coles, 2005). As such, TA can be considered as a way of institutionalizing societal concerns (topdown), which previously spontaneously generated from the concerned communities (bottom-up).

In the debate on gene technology, the traditional social partners, employers and employees, were joined by environmental and consumer organizations. Biotechnology also captured the attention of academics in environmental philosophy and ethics who questioned the moral acceptability of this specific interference of man with his natural environment (e.g., playing God, sanctity of nature). At least "theoretically," they attempted to relate agro-biotechnology to ethics. In 1978, the Recombinant DNA Advisory Committee expanded to include also lawyers, ethicists, political scientists, and consumer advocates.

The first deliberate releases of transgenic organisms into the environment in the eighties generated more focused discussions on their potential environmental (agro-ecological) risks. Although it was widely acknowledged in the seventies that GMOs would be deliberately released into the

\footnotetext{
${ }^{10}$ Following the adoption of the Technology Assessment Act in October 1972, the OTA was established to serve the US Congress.
} 
environment, their potential environmental risks were never effectively addressed. The Recombinant DNA Safety Considerations (the so-called Blue Book) published by the Organization for Economic Cooperation and Development (OECD) in 1986 was the first intergovernmental document addressing the environmental safety of transgenic organisms. With these evolutions, ecologists, evolutionary biologists, epidemiologists, and other environmental specialists joined the GMO debate. The idea that environmental risk assessment should be conducted stepwise on a case-by-case basis gained adherents. The case-by-case approach considers source and target environments, biological, and ecological characteristics of transgenic organisms, and scale and frequency of introductions; whilst the stepwise approach relies on an increase in complexity and realism based on the knowledge gained during previous steps (e.g., in the laboratory) (Andow and Zwahlen, 2006). It was recognized that classifying types of activities and organisms into risk categories was not the most appropriate approach for environmental risk assessments. The Blue Book and the ecological considerations and recommendations about the deliberate release of GMOs of the Ecological Society of America (Tiedje et al., 1989) contributed to the achievement of international consensus on this case-by-case and stepby-step procedure in environmental risk assessment.

\section{4. "Bioethics" in Biomedicine and in the Debate on Transgenic Animals}

The first gene therapy experiments and the debate on transgenic animals evoked concerns on human health and animal welfare, which were explicitly labeled "bio-ethical." In 1980, Martin Cline's gene therapy experiment failed. ${ }^{11}$ Subsequently, the NIH suspended Cline for having conducted an unauthorized r-DNA experiment. This affaire not just provided questions about the riskiness of the technique itself, but also about the acceptability and regulation of premature experiments, the possibility of irreversible manipulations of human genes, the rights of patients, and the responsibilities of medical doctors executing the experiments. With the advent of transgenic animals (e.g., Herman the bull, Tracy the sheep) and under strong influence of animal welfare organizations in some countries (e.g., the Netherlands, Denmark), animal welfare became an important source of societal controversy. Objections not only related to the possibility of negative consequences for health and welfare of the modified animals, but also

\footnotetext{
${ }^{11}$ In 1980, Martin Cline conducted r-DNA transfer into the bone marrow cells of two patients with hereditary blood disorders. He did so in direct opposition to the NIH gene therapy guidelines and without the approval of the Institutional Review Board at the University of California, where the research was conducted.
} 
to the direct "unnatural" intervention in the genome of animals as it affects their integrity (De Vries, 2006).

These developments entailed three trends in the "institutionalization of ethics." First, the established network of local, hospital, and academic research ethics committees were centralized and came under state control. Ethical committees were composed of professionals in medical and life sciences, law, religion, and philosophy. Second, national centralized bioethics committees were created, which were in charge of considering ethical implications in biomedical research in general (including ethical aspects of biotechnology). Third, regulations were implemented, encompassing moral and ethical principles (Lindsey et al., 2001).

With the increased media attention on bioethical issues, the ethical discourse took a central role in the societal debate on biotechnology. This was amplified by the birth of Dolly the cloned sheep in 1996 and the various statements prohibiting human cloning.

\section{RESTYLING THE EU LEGAL FRAME ON GM CROPS}

Since the end of the eighties, genetically engineered agro-food products physically entered the public sphere. This trend was first observed in the US, and rapidly spread to Europe. Whereas initially, GM crops were restricted to and confined in research and development laboratories, they now gained presence in agricultural fields, in supply chains and - to a lesser extent - on supermarkets' shelves and on consumers' plates.

\subsection{Societal Commotion Revealing a "Complex of Concerns"}

In the US, the advent of GM agro-food products caused little public controversy (Winickoff et al., 2005). However, in European civil society, the physical entrance of GM agro-food products in the public sphere enriched the ongoing debate with new actors and concerns.

In April 1996, the first shipments of transgenic soybean and/or maize grown in the US were blockaded by non-governmental organizations (NGOs). Under influence of both intensive NGO campaigns and growing media attention, consumers boycotted GM agro-food products. To respect the preferences of consumers and to maintain their confidence in product quality, major supermarket chains excluded GM ingredients from their own-brand food products. The food industry adopted negative labeling to guarantee the absence of GM material in foodstuffs. Retail food chains launched bans against products from animals reared on feed produced from GM crops (Levidow and Bijman, 2002). 
Reinforced by the growing societal anti-GMO sentiment, the safety assessment of GM agro-food products evoked serious regulatory-expert disputes between safety assessment bodies (Levidow, 2001). Conflicting positions were at play about (i) the kinds of harm to assess or to ignore, (ii) the baseline of comparison to use for assessing the severity and acceptability of harm, (iii) the reliability of scientific evidence, and (iv) the means of managing uncertain risks (Carr, 2002). Several Member States (MS) defined "harm" in broader ways than some of the involved EU institutions. Hereby, they invoked national "safeguard clauses" to provisionally restrict or prohibit the use and/or sale of authorized GM agro-food products on their territory. Also various NGOs urged to take broader precautionary accounts, for instance, by linking "harm" to a discourse about "sustainability." They emphasized that judgments about the acceptability of impacts not only should be based on conventional farming, but also on organic or integrated farming in order to strike a new balance between agricultural production and biodiversity (Levidow et al., 2005). In this context, GM agro-food biotechnology was perceived as aggravating the problems of intensive agriculture, and as bringing unpredictable, uncontrollable, involuntary and unfairly distributed risks (Levidow and Carr, 2007).

Some scientists, regulators, and NGOs started to question the domination of biotechnologists in regulatory and expert arenas, as well as the appropriateness of small-scale, short-term, and strictly confined field trials in forecasting risks under real agro-ecological situations over a longer timeframe. Public suspicion towards scientists, policy makers, industry, and GM agro-food products was nourished by a number of events, such as the objections made by UK's Prince Charles, the scientist Arpad Pusztai announcing on British television that rats fed with GM potato - modified to express snowdrop bulb lectin - suffered adverse health effects, and a series of food safety scandals. Increased media coverage reflected the bold rhetorical and metaphorical risk discourses of both GMO opponents and proponents, which further intensified the debate. Emphasizing the dangers of and even the "immorality" of transgenic agro-food products, the image of Frankenstein has been and today continues to be widely used as a metaphor in the GMO debate. It is a strong metaphor, which sidesteps rational arguments, whilst creating and evoking images that echo existing cultural narratives, in this case possibly inviting strong emotional responses against biotechnological developments (Gamson and Modigliani, 1989; Schuurman et al., 2006). As such, the mass media explicitly got enrolled in public perception and societal image building of biotechnology, leading to the social amplification of risk (Kasperson and Kasperson, 1996).

Before, the GMO debate mainly had been framed as an objectivist risk issue, i.e., concerns that fell outside the scope of the risk discourse were 
dismissed on grounds that they were not scientific. However, gradually, more and different ethical and socio-economic concerns entered the debate. In France, for instance, anti-globalization leaders reframed the debate as an issue on food quality whereby topics such as paysan expertise, cultural homogenization, and globalization were given specific attention (Heller, 2002). Questions also arose about the agronomic and socio-economic relevance of transgenic crops, their usefulness and sustainability, the wanted type of food and agriculture, the standardization of food, and the concentration of biotechnology companies. According to these anti-globalists, agro-biotechnology undermines less-intensive agricultural methods and high quality products, and represents a threat of greater farmer dependence on biotechnology companies (Levidow and Carr, 2007). Because of the destruction of various experimental field trials all over the EU and the resulting court cases, and because of governmentally funded participatory exercises, the GMO debate also became a local political issue, covering issues such as the legitimacy of civil disobedience, and the function and independency of public research (Bonneuil et al., in press). Moreover, whilst minor crops and engineered traits remained largely ignored, the fact that the worldwide growing area of GM crops only covered a few commercially important crops and traits was connected to the dominance of the private sector in research, development, and commercialization of transgenic crops, the increased alignment of universities with the private sector, and the general decrease in crop diversity (Welsh and Glenna, 2006). Also the high regulatory costs and hurdles were referred to as blocking factors for the commercialization of transgenic crops by academic and governmental research institutions and small biotechnology companies (Bradford et al., 2005).

And more issues have emerged in the GMO debate. The co-existence between cropping systems and the adventitious mixing of GM and non-GM agro-food products became much discussed topics (Levidow and Boschert, in press). According to the co-existence policy in the EU, the ability of farmers to make a practical choice between conventional, organic, or GM crop production should be ensured, without excluding any agricultural option (Devos et al., 2005). In practice, however, not only did various actors perceive GM crops as a threat to other crop productions and even to ecologically sensitive regions (Verhoog et al., 2003; Altieri, 2005), also an impressive number of "GM crop free zones" were created all over the EU and a "network of GMO-free regions" was installed. With the creation of a network of GMO-free regions, regional and local governments and municipalities and farmers that were muted in the GMO debate forged coalitions and succeeded in putting their prerogatives (including their sovereignty) on the agenda. By banning GM crops on their territory, they are 
defending a specific model of future agriculture against the current agroindustrial model: i.e., the post-productivist or sustainable rural development model (Marsden and Sonnino, 2005).

To ensure the co-existence between cropping systems, national and/or regional authorities now are developing legal co-existence frames in which various on-farm management measures are set (e.g., Devos et al., 2004, 2005, 2007), and in which liability provisions for economic damage are assigned. ${ }^{12}$ However, this appears to be an extremely difficult task. Preliminary assessments of these legal proposals have already confirmed that certain cropping systems are often favored over others (European Commission, 2006). Also the tolerance threshold ${ }^{13}$ for the unintentional or technically unavoidable presence of authorized GM material in non-GM products captured important criticism, especially by organic growers who plead for a zero tolerance instead of a tolerance currently set to $0.9 \%$. In contrast, proponents claim that co-existence is feasible, but that opponents use it as a pretext to place new barriers on the path of GM crops. Hence, the previously unsolved conflicts over GM crops condensed onto co-existence, which became another arena for contentious values and ideals.

All these evolutions reveal a "complex of concerns" that largely exceeds the safety issues under discussion at the Asilomar conferences. In this complex, any distinctions between environmental, agricultural, and socioeconomic issues prove to be blurred, fueling the confusion about the wider debate about genetic modification and the risk assessment of GM crops in the EU.

\subsection{Restyling of EU Legislation as a Response to Societal Commotion}

Since the nineties, a harmonized process-based regulatory frame for GM crops destined for food, feed, cultivation, import, industrial processing, and experimental uses is installed in the EU. ${ }^{14}$ The use of GM agro-food products is subjected to a risk analysis prior to use, consisting of risk assessment and risk management. In risk assessment, potential adverse impacts associated with a specific activity are scientifically characterized, whilst in risk management, policy alternatives to accept, minimize, or reduce

${ }^{12}$ Due to a lower market price, labeling mixed products can cause a loss of income.

13 A tolerance threshold refers to the maximum admixture level for GM content under which the co-mingled product does not have to be labeled as consisting of, containing, or being produced from a GMO.

${ }^{14}$ In 1986, the US Office of Science and Technology Policy issued the Coordinated Framework for Regulation of Biotechnology. Within this context, the American government decided that GMOs must be regulated under existing legislations, resulting in a product-based approach. Unlike the situation in the EU, in the US, GMOs thus are subjected to stricter rules only when the end products are not substantially equivalent to their conventional counterparts. 
the characterized risks are weighed and, if needed, appropriate prevention and control options are selected.

Despite the existence of this regulatory frame, the opposition towards GM agro-food products grew and contributed to a de facto moratorium hindering the commercialization of new GM agro-food products in the EU. At the June 1999 meeting of the Environmental Council, Austria, Denmark, France, Greece, Italy, and Luxembourg decided not to accept new market consents of new GM crop events as long as the existing regulatory frame was not revised. Austria, Belgium, Finland, Germany, Spain, Sweden, and the Netherlands did not go as far, but stated that they would take more precautionary accounts for the assessment of new market consents (Winickoff et al., 2005).

From this period onwards, a reorientation took place. Via various waves of institutional reforms, a gradual revision of the existing legislations and the creation of new EU institutions were devised in order to restore public and market confidence (Devos et al., 2006). In response to the societal concerns about harmfulness and scientific uncertainties related to GM agrofood products, various scientific and technical reforms were made at the level of the risk analysis: (i) the environmental risk assessment was differentiated from the product-specific ones (e.g., foods and feeds), (ii) risk assessment methodologies and approaches were harmonized, and (iii) new institutions such as the European Food Safety Authority (EFSA) were created to provide "independent, objective and transparent" science-based advice. A more streamlined and less cumbersome authorization procedure, centralized around the EFSA, was introduced through the "one door, one key" approach. Hence, the societal demands that focused on the availability of safe GM agro-food products for consumers, and the protection and maintenance of the environment and its biodiversity were taken seriously in the new regulatory frame. In terms of "labeling," "traceability," "co-existence," and "public information," legal answers were formed to the general desire of the public for more information about GM agro-food products, and the specific demand to respect the consumers' and farmers' freedom of choice (Brom, 2000; Mepham, 2000).

In the restyled European regulatory frame on GM agro-food products, two legal "openings" have been created, which were explicitly labeled as ethical. First, the consultation of an ethics committee for ethical issues of a general nature is allowed during the authorization procedure. Second, the labeling of GM agro-food products is imposed when the presence of GM material gives rise to ethical or religious concerns. The precise meaning of these concerns is not further clarified. Nevertheless, since nowadays the sole use of genetic modification is already a sufficient reason to justify labeling, 
ethical and religious concerns of consumers indirectly have been taken seriously.

Also various implicit links to ethics can be revealed in the new regulatory frame. For instance, the "precautionary principle" was explicitly adopted in 2002 as a way to cope with scientific uncertainties in risk analysis. This involved (i) the enlargement of the scope of the environmental risk assessment with direct, indirect, immediate, delayed, and cumulative long-term adverse effects, (ii) the need to render value judgments and the limitations of risk assessment more explicit, (iii) the mandatory adoption of precautionary measures such as environmental post-market monitoring and traceability, (iv) the phasing out of certain antibiotic resistance marker genes with clinical relevance, (v) the strengthening of the duty of re-examination of risk analysis by limiting the duration of market consents to maximum 10 years, and (vi) finally, also the consultation of members of the public became mandatory in the authorization procedures.

\subsection{Restoring Public and Market Confidence}

Based on the legal changes discussed above, one could conclude that de facto moratorium gave room to a broader discussion, adding a societal dimension to the existing regulatory frame. However, the various institutional reforms, although leading to the upheaval of the de facto moratorium in 2004, did not dissipate the societal disjuncture. As Gaskell et al. $(2006: 19,28)$ put it, "the new regulatory frame appears to have done little to allay the European public's anxieties about agro-food biotechnology," and "the years of controversy have led many people in Europe to believe that anything that has to do with GM food is undesirable." Despite institutional reforms, the lasting skeptical and/or ambivalent attitude towards GM agro-food products reveals that there is a long way to go in order to restore public confidence in scientists, policy makers, and regulatory institutions. Even more, today, a (technological) stigma seems attached to agro-food biotechnology, especially to its resulting GM agro-food products. A stigmatization of agro-food biotechnology is supported by its invisible and potential dangers, the repulsive (Frankenstein) images unleashed in the public sphere by various NGOs, their origin in the chemical industry, unclear responsibilities in case of environmental damage, scientific uncertainties and ignorance related to cumulative long-term adverse effects, their frequent occurrence in the news through reports of contamination, etc. Being "labeled" as blemished and tainted under a "Frankenfood" banner, the combined riskiness, undesirability, and unnaturalness of these products as a whole (as an "icon"), are pinpointed (Gregory et al., 2001; Kasperson et al., 2001). All this not only affects the dominant "image" of biotechnology in general and GM 
agro-food products in specific in the public sphere, but also marks the strategic, financial, and market driven decisions in academic and private research.

According to various researchers, public and market confidence may be restored by clarifying and accommodating different values and ideals held in decision-making, enhancing public accountability, democratizing expertise, and by creating a shared responsibility for decision-making (Healy, 1999; Levidow and Marris, 2001; Wynne, 2001; Jensen and Sandøe, 2002; Mayer and Stirling, 2002; Jasanoff, 2003; Jensen et al., 2003; Frewer et al., 2004; Wandall, 2004; Deblonde and du Jardin, 2005; Genus and Coles, 2005; Winickoff et al., 2005; Irwin, 2006; Jensen, 2006; Power and McCarty, 2006). Although gaining trust may be harder than losing it, in the regulatory process of decision-making about GM agro-food products, this objective can be achieved by (1) making scientific risk assessments more transparent by denoting explicitly the factual and normative premises on which they are based, (2) allowing the contribution of diverse publics through the organization of participatory exercises, and by (3) implementing an integral sustainability evaluation that integrates societal concerns. The question is how these recommendations are implemented in the European regulatory frame on GM crops and translated in the regulatory practice of decision-making.

\subsubsection{Making scientific risk assessments more transparent}

In daily practice, several MS continue to raise safety objections and thus to dissent from the scientific opinions of the EFSA. Subsequently, decision proposals of the EC gain little support from MS. These trends recently entailed a policy shift towards greater transparency about scientific uncertainties, plural viewpoints and about value judgments in risk assessment of GM agro-food products (European Food Safety Authority, 2006; Levidow, 2006). With this shift and with the explicit adoption of the precautionary principle, it was recognized that risk assessment can be limited by a degree of scientific uncertainty, ignorance, indeterminacy, ambiguity, and inconclusiveness, and that decisions must be made acknowledging that these shortcomings may not be resolved (van der Sluijs, 2007). Moreover, it was accepted that scientific expertise should be pluralized in risk assessment in order to render more explicit which value judgments about the acceptability of harm are at play, and to take into account the permanent interplay between risk assessment and risk management. That risk assessments conducted by various European and national expert committees often give different outcomes is illustrative of the fact that various interpretations are given, values and ideals held, institutional cultures detained, and precautionary accounts taken. For example, Austria and Germany, respectively, take organic and integrated farming as a normative baseline for the evaluation of adverse effects, instead of conventional 
farming. This leads to divergent estimates of risk between different MS and EU institutes. This very choice alone illustrates that risk assessment does incorporate value and policy judgments: normative priorities set by risk managers dictate which thresholds, methodologies, and working assumptions should be used in conducting risk assessment (Levidow and Marris, 2001; Wynne, 2001; Jensen et al., 2003; Wandall, 2004; Levidow et al., 2005; Winickoff et al., 2005; Haller and Gerrie, 2007; van der Sluijs, 2007). Rendering these choices and their implications more explicit may be one step forward in the establishment of a transparent, modest, and pluralistic expertise in contested risk situations, enabling risk managers to judge whether the factual basis of risk assessment is sufficiently reliable to act upon (Jasanoff, 2003; Nowotny, 2003). Still, once value judgments have been made clear, it remains to be seen how they will be dealt with in practice. They certainly will not make things less complicated and may even lead to new challenges. Indeed, how will risk managers set up their practice if they can no longer work with straightforward opinions? There is also the concern that an explicitation of expert disagreement, subjectivity, and policy influence may further reduce public credence in a science-based policy (Levidow, 2006; van der Sluijs, 2007).

\subsubsection{Allowing the contribution of diverse publics}

The possibility to consult both members of the public and an ethics committee during the regulatory procedures for marketing, allows attempts to democratize and further pluralize expertise in decision-making. It also enables risk managers to consider divergent interpretations of scientific uncertainties and of the underlying values and ideals held by different actors. Even more, the public seems to be more inclined to accept decisions if consultations can be seen as "fair" and "balanced," even when outcomes are at odds with their preferences. However, in practice, the role of public participation and/or ethical consultation is at best symbolic. Generally, only scientific and technical comments are considered during the public consultation, whilst larger societal concerns are excluded beforehand (Mayer and Stirling, 2002). Hence, societal demands falling outside the scope of the risk discourse continue to be dismissed on grounds that they are not scientific. Moreover, the ethical assessment is not even supposed to stop or delay the authorization procedure or to change the decision content (Jensen et al., 2003; Madsen and Sandøe, 2005). Practical problems in making direct public engagement and the inclusion of societal concerns in decision-making workable can be invoked as causes (Karlsson, 2003; Myhr and Traavik, 2003; Genus and Coles, 2005; Hagendijk and Irwin, 2006; Irwin, 2006; Beekman and Brom, 2007). It may also reflect the difficulty to fully coincide 
narrow and stringent legal frameworks with complex, large, and often fluctuating ethical concerns.

In addition to this mere symbolic presence of public participation in market decisions on GM agro-food products, labeling provisions limited the involvement of citizens in decision-making to consumers' involvement. The sole political power of citizens is "to buy or not to buy" GM-labeled products that are on the market. This narrowed "ethics" to the private/ individual sphere. Also, intrinsic moral concerns of people perceiving GM agro-food products as "unnatural," as "a violation of the sanctity of species," as "disrespectful for nature" or as "incompatible with organic farming" remain unaddressed in decision-making (Brom, 2000; Streiffer and Hedemann, 2005; Streiffer and Rubel, 2004). When people reject GM food, they are expressing "unease at the prevalent direction of the agro-food system, which remains beyond democratic control; they can see no political means to influence decisions" (Levidow and Marris, 2001: 352). With the adoption of a co-existence policy, the wider debate about the acceptability of GM crops further shifted to the private/individual sphere: farmers are in charge of deciding whether they want to cultivate authorized GM crops or not. Hence, one can conclude that the concept of ethics remains little explored in the regulatory process of decision-making.

\subsubsection{Implementing an integral sustainability evaluation}

An integral sustainability evaluation may be helpful in recovering public and market confidence, as it integrates larger societal concerns by placing agro-food biotechnology in the context of a whole agricultural system. As described earlier, the assessment of transgenic agro-food products has intersected with a wider debate about "sustainable agriculture" in the EU, blurring any distinctions between environmental, agricultural, and socioeconomic issues. With such an integral sustainable evaluation, defining and integrating the underlying values at stake, trading possible risks against benefits, comparing technological alternatives, testing the usefulness of transgenic crops, and assessing a whole agricultural system become possible. It may promote finding a better balance between agricultural production and biodiversity, and evolving towards a socially more robust risk analysis.

Nowadays, the EU regulatory frame does not allow considerations of potential benefits and socio-economic issues in the risk analysis of GMOs. Legal objectives mainly aim at (i) creating an internal market, (ii) ensuring a high level of protection of human health, animal health, and the environment, (iii) enabling consumers and farmers to exercise effectively their freedom of choice in the market place, and (iv) not misleading consumers and users (Devos et al., 2006; Jensen, 2006). There is no legal room to evaluate whether GM crops fulfill wider socio-economic and environmental 
aspirations, and thus to evolve towards a sustainability assessment. Moreover, linking the use of the precautionary principle to the ideal of sustainable development seems to be hampered, as its use is kept within a narrow scientific context (Deblonde and du Jardin, 2005; Levidow et al., 2005).

To conclude, although different legal changes have been made and at least on a general level several societal concerns have been implemented, the controversy about and stigma on transgenic agro-food products still hold. With the solidification of a risk-based policy in the restyled regulatory frame, decision-making in fact only poorly integrates societal concerns and differing values at play in the GMO debate. In principle, decision-making relies on risk analysis, in which wider "non-scientific" concerns are reflected (Madsen and Sandøe, 2005; Johnson et al., 2007). In practice, decisionmaking continues to be solely based on risk assessment, although it is widely acknowledged that objective scientific and technical knowledge is only one part of risk analysis. Due to the safety objections raised by some MS, a qualified majority is rarely reached at the Council of Ministers. As a last resort, it is the EC that is in charge of decision-making to avoid the legal gridlock. In this decision-making phase, the EC generally follows the favorable scientific opinion of the EFSA. As such, only "reasonable" societal concerns entering the risk framing are considered in risk analysis, whilst the remaining ones are dismissed. Even within risk assessment, it has been argued that scientific uncertainties are poorly integrated and that value judgments are made by experts in ways that are not transparent, both reinforcing the notion that expert advice would be value-free and neutral (Levidow, 2006). Hence, the gap between scientific and social rationality seems to be maintained: "social movements raise questions that are not answered by the risk technicians, and the technicians provide answers that miss the point of what was asked and what is feeding public anxiety" (Finucane and Holup, 2005: 1604). Altogether, this reflects the "inherent limitations to the practical usefulness of risk assessment in policy disputes" (Freudenburg, 1996: 44; Levidow et al., 2005). While decision-making is evidence-based, social decision-making is not similarly constrained (Power and McCarty, 2006). For these reasons, the Sense and Sensibility (re)quest to move from a merely reliable risk-based policy towards a socially more robust one - in which normative premises are denoted explicitly and in which differing values and ideals held are accounted for in decision-making - is still very much alive. Knowledge used for decision-making should not only be excellent from a scientific and technical point of view, but also needs to be socially robust (Levidow and Marris, 2001; Jasanoff, 2003; Nowotny, 2003). In the words of Beck, "scientific rationality without social rationality remains empty, but social rationality without scientific rationality remains blind" (Beck, 1992: 30). 


\section{RESTYLING SCIENCE COMMUNICATION}

The continuing controversy about GM agro-food products can be interpreted as an expression of the difficulty of policy measures to meet and appease societal concerns. That societal concerns are complex is reflected in the restyling of science communication models, in which models have increased in complexity and reflexivity to cope with the skeptical and/or ambivalent attitudes towards agro-food biotechnology. However, also here a better understanding of values underlying perceptions of risk, and the role of the media in framing the GMO issue in the public sphere is needed. A deeper insight into public attitudes and their role in the dynamics of the GMO controversy may ultimately improve decision/policy-making.

\section{1. "Science Literacy" or "Deficit" Model}

The movement that relied on the "science literacy" or "deficit" model played an important role in the public communication and understanding of science and technology. The overriding discourse in the late eighties and early nineties was that public concerns about biotechnological developments stemmed from either an incorrect understanding of this technology or a lack of scientific literacy/knowledge (Logan, 2001; Gross, 1994; Wynne, 2001). Public attitudes often were depicted as subjective, emotional, hysterical, unscientific, and as false risk perceptions (Freudenburg, 1996). In that vein, the public was perceived as a national unity of lay people with variable levels of scientific literacy (Horst, 2007). Since a higher level of scientific literacy was thought to improve public support of science and its technological applications, more and better communication of scientific facts was assumed to be the appropriate answer to dissolve societal concerns (Bodmer, 1985). In other words, "knowing science" was "to approve of science." In this perception, the task of the media is to transmit the fixed scientific facts from the scientists' world towards lay people, and should this unidirectional information flow be obstructed from educating them, then the sensationalist tendencies of the media are said to be blamed (Wynne, 1995). For this reason, the media have been represented as a "dirty mirror," located in between science and the public (Dornan, 1990; Bucchi, 1998). The concept of science as "pure or objective discovery" has political and ethical consequences: when science is given a monopoly on truth, no fundamental questions or doubts about the direction of scientific research, technological applications, or implementations in social or medical policy are to be settled. The main aim is emancipation, leaving neither room for societal TA, nor for any re-moralizing of social life. As such, it is a debate about "facts," not about any kind of "ethics." 


\section{2. "Science Literacy” or "Deficit” Model Tackled by ...}

In the mid nineties, several disciplines criticized the characterization of societal concerns as a deficit in scientific knowledge. Risk communication studies and survey analyses on the public understanding of science have revealed that although more knowledgeable people generally tend to be more positive about science and technology, they also tend to be more concerned and ambivalent regarding contentious research areas (Evans and Durant, 1995; Gutteling and Wiegman, 1996; Löfstedt and Frewer, 1998; Frewer et al., 2004).

Communication science and media studies added that communication effects are not linear, and that the interpretation of information - including scientific "facts" - occurs in a certain social, political, economic, or ethical context. As a result, a simple information transfer will not lead to homogeneous attitudes or behavior. Moreover, the content of information may suffer from its transfer from one context to another (McQuail, 2006), since information is both constructed and transformed in the communication process (Bucchi, 1998).

Sociologists of science attributed the cause of societal concerns to a deficit in sociological knowledge. They argued that credibility and trust should not be considered as intrinsic properties of information. On the contrary, they depend on social solidarity and on processes of social identity-construction (Wynne, 1992; Irwin and Wynne, 1996): people experience, define and judge the usefulness and relevance of scientific knowledge in their social life. Therefore, the public should be viewed as composed of locally situated groups, each of which makes sense of scientific knowledge in its own way. "When viewed in their local contexts, particular instances of sense-making, previously characterized as 'deficient,' now seem perfectly reasonable" (Horst, 2007: 152).

\section{3. "Public Engagement with Science and Technology"}

The "public engagement with science and technology" movement, emerging at the end of the nineties introduced a "new mood for dialogue." Focus was not only put on institutionally oriented top-down processes, but also on the bottom-up sense-making processes of people (Maeseele, 2007). On the one hand, the movement set forth the various forms of engagement that people may have with science and technology. For this reason, public support may only be retrieved by recognizing and respecting public's attitudes and values, and by weighing them along with scientific factors. On the other hand, institutions should respond to the people's demands through greater transparency, openness, and public participation. To ensure the socially accountable development of transgenic agro-food products, various 
engagement initiatives (e.g., consensus conferences, participatory TA initiatives, citizens' panels) so far have been organized. However, in the face of a much debated demand for a cultural change in key decision-making and scientific institutions, these participatory initiatives seem to be only isolated events with limited public visibility and ability to shape the trajectory of GM legislation and development (House of Lords, 2000; Genus and Coles, 2005; Hagendijk and Irwin, 2006). The focus should be both on the software of engagement (values, codes) and on the hardware (participation procedures) (House of Lords, 2000; Wilsdon and Stilgoe, 2005). Nevertheless, it remains to be seen whether similar governmental discourses merely represent a discursive shift or, on the contrary, a genuine epistemological shift at public policy level (Irwin, 2006). Otherwise, this "talking the talk without walking the walk" would be quite similar to the higher mentioned rather symbolic participation in the restyled EU regulatory frame.

\section{CONCLUSION}

Like the intricate web of Sense and Sensibility, described in Austen's novel, the societal debate on GMOs presents itself as a continuous and complex process re (quest) to give "sense to sensibility," whilst simultaneously letting "sensibility guides the making of sense."

Since its conception more than three decades ago, the debate largely extended in scope of actors involved and concerns addressed. Scientists' initiatives such as the Asilomar conferences and the governmentally linked establishment of TA form the roots of the GMO debate. At Asilomar, the safety of laboratory workers and their neighborhood was questioned by the scientific community for the first time, already flavoring the debate with an implicit ethical dimension. TA broadened the aspects under study by evaluating the socio-economic impact on society of biotechnology. It enlarged the spectrum of involved actors with traditional (trade unions, employers' organizations) and other social partners (environmental and consumer organizations), and by taking the general public or civil society into account. Biotechnology also captured the attention of academics in environmental philosophy and ethics, who questioned the moral acceptability of the interference of man with his natural environment.

The growing influence of private financing and the commercialization of genetic engineering, together with the institutionalization of the critical questioning of science all influenced the scientific community. That scientific academics became entrepreneurs or were financed by private capital had implications for their moral positions. With knowledge becoming a 
commodity for private profit, questions arose about the patentability of natural parts of life forms, and about the hybridization between fundamental and applied research. Hence, scientific objectives became intertwined with extra-scientific (e.g., socio-economic/commercial) ones.

In the development of biotechnology from laboratory science to society, the emergence of concerns explicitly labeled as ethical was associated to a specific momentum: "ethics" explicitly entered the picture with the first gene therapy experiments on humans and with transgenic animals.

Transgenic crops and agro-food products, initially restricted to confined laboratories, gained presence in agricultural fields, in supply chains, on shelves of supermarkets, and on consumers' plates in the EU, thereby directly and physically entering the public sphere. The dynamics of this intertwined "science-industry-public sphere" network received strong input from successive and various incidents (such as food safety scandals), from the failure of the government to anticipate and manage these incidents, from the bold metaphorical and rhetorical discourses of both GMO proponents and opponents, and from the growing public distrust. This led to the gradual arousal of a "complex of concerns" that largely extended the initial risk framing of the GMO issue. In this complex, any distinctions between environmental, agricultural, and socio-economic issues proved to be blurred, fueling the confusion about the wider debate about genetic modification and the risk assessment of GM crops.

To improve public and market confidence, the existing European regulatory frame on the commercialization of transgenic crops was deeply revised during the de facto moratorium. The adoption of the precautionary principle, post-market environmental monitoring, and traceability currently is seen as a way to cope with scientific uncertainties; whilst labeling, traceability, and co-existence provisions are attempts to take the demand of the consumers' and farmers' choice seriously. Although attempts have been made to democratize and pluralize expertise in decision-making, public participation or ethical consultation has been shown to be at best symbolic. Intrinsic moral concerns also prove to be a hard nut to crack in terms of legal commitments, as the ethical question has been brought to the private/ individual sphere. Finally, a new challenge already presented itself: the implementation of an integral sustainability evaluation. So far, however, it seems that a risk-based policy is further solidified. As such, the (re)quest to accommodate many societal concerns and differing values at play in the GMO debate continues to play with regard to the risk analysis of GM agrofood products.

Also models on science communication went through a restyling in order to cope with the skeptical and/or ambivalent public attitudes towards agro-food biotechnology. After the deficit approach that saw the 
solution in making lay people think more like scientists or risk experts failed, the discourse gradually shifted from an emphasis on scientific literacy towards public engagement and participation. The latter explicitly aims to cope with the non-scientific concerns lay people rely on when perceiving risk. This trend towards a "rational orchestration" of the public voice is confirmed by the growing amount of consensus conferences and citizen panels in science evaluating processes. Several observers have noted, however, that these participatory events rarely allow the examination of wider societal and ethical concerns, and are of secondary importance to the much debated demand for a cultural change in key decision-making and scientific institutions. It thus remains a huge challenge to take the wide range of societal concerns seriously in both communication and decision-making.

The complex of concerns and actors described in this paper is a dynamically evolving complex. New studies are needed to understand how, and in how far, the societal concerns discussed are at play today and how much "ethics" is still an issue in biotechnology. Although ethics seems to play less overtly in today's public sphere, one cannot conclude that in the case of agro-food biotechnology ethics is dead. To the contrary, the lasting skeptical and/or ambivalent attitude of Europeans towards agro-food biotechnology and the continued controversies about the commercialization of transgenic agro-food products are illustrative of an ongoing legitimacy crisis. One could even interpret the stigma on agro-food biotechnology and its products as testifying to a "robust" societal disapproval: it signals a lack of trust in scientific institutions and expert systems, and voices a social response against the reduction of the complexity of the GMO issue to a solely scientific risk-based problem. Hence, a move from a merely scientific evaluation towards a socially more robust one - that addresses precaution and socio-ethical issues in a more "sensible" way, whilst making "sense" of the different stances taken in the GMO debate is still sought for. As such, the (re)quest for Sense and Sensibility seems to have been partially fulfilled (e.g., the restyled EU regulatory frame, participatory initiatives), partially evaded (e.g., Gelassenheit), and partially shifted towards new topics (e.g., co-existence, molecular farming, nanobiotechnology, biofuels). It will be interesting to see whether new controversies show (triggered, for example, by GMO contaminations or traces of unapproved transgenic events in non-transgenic produces), how these will be communicated and developed in the societal climate, and how they will be interpreted and tackled by, and/or lead to new adjustments in the now running legal system. 


\section{ACKNOWLEDGMENTS}

This research is financially supported by the Ghent University (GOA Project $\mathrm{N}^{\circ}$ 01GA0105). Linda Van Speybroeck is a FWO Postdoctoral Fellow. We thank Didier Breyer, Nicolas de Sadeleer, Adinda De Schrijver, Marian Deblonde, Lieve Goorden, Dirk Holemans, Shane Morris, Gertrudis Van de Vijver, and Willy Weyns for inspiring discussions. Thanks and appreciation is also extended to the anonymous reviewers for their constructive comments on the manuscript.

\section{REFERENCES}

Abels, G. (2005), "The Long and Winding Road from Asilomar to Brussels: Science, Politics and the Public in Biotechnology Regulation." Science as Culture, 14, pp. 339-353.

Altieri, M. A. (2005), “The Myth of Coexistence: Why Transgenic Crops are not Compatible with Agroecologically Based Systems of Production." Bulletin of Science, Technology \& Society, 25, pp. 1-11.

Andow, D. A., and C. Zwahlen (2006), "Assessing Environmental Risks of Transgenic Plants.” Ecology Letters, 9, pp. 196-214.

Barinaga, M. (2000), “Asilomar Revisited: Lessons for Today?.” Science, 287, pp. $1584-1585$.

Beck, U. (1992), Risk Society. Towards a New Modernity, London: Sage Publications.

Beck, U. (1999), World Risk Society, Malden MA: Polity.

Beekman, V., and F. W. A. Brom (2007), "Ethical Tools to Support Systematic Public Deliberations about the Ethical Aspects of Agricultural Biotechnologies." Journal of Agricultural and Environmental Ethics, 20, pp. 3-12.

Berg, P., and M. Singer (1995), "The Recombinant DNA Controversy: Twenty Years later." Proceedings of the National Academy of Sciences of the United States of America, 92, pp. 9011-9013.

Berg, P., D. Baltimore, H. W. Boyer, S. N. Cohen, R. W. Davis, D. S. Hogness, D. Nathans, R. Robin, J. D. Watson, S. Weissman, and N. D. Zinder (1974), "Potential Biohazards of Recombinant DNA Molecules." Science, 185, pp. 303.

Berg, P., D. Baltimore, S. Brenner, R. O. Roblin, and M. F. Singer (1975), "Summary Statement of the Asilomar Conference on Recombinant DNA Molecules." Proceedings of the National Academy of Sciences of the United States of America, 72, pp. 1981-1984.

Bevan, M. W., R. B. Flavell, and M. D. Chilton (1983), "A Chimaeric Antibiotic Resistance Gene as a Selectable Marker for Plant Cell." Nature, 304, pp. 184-187. Bodmer, W. (1985), The Public Understanding of Science, London: Royal Society. Bonneuil, C., P. B. Joly, and C. Marris (in press), "Disentrenching Experiment? The Construction of GM-crop Field Trials as a Social Problem in France." Science, Technology and Human Values. 
Bradford, K. J., A. Deynze, N. Gutterson, W. Parrott, and S. H. Strauss (2005), "Regulating Transgenic Crops Sensibly: Lessons from Plant Breeding, Biotechnology and Genomics." Nature Biotechnology, 23, pp. 439-444.

Brom, F. W. A. (2000), "Food, Consumer Concerns, and Trust: Food Ethics for a Globalizing Market." Journal of Agricultural and Environmental Ethics, 12, pp. 127-139.

Bucchi, M. (1998), Science and the Media. Alternative Routes in Scientific Communication, London/New York: Routledge.

Carr, S. (2002), "Ethical and Value-based Aspects of the European Commission's Precautionary Principle." Journal of Agricultural and Environmental Ethics, 15, pp. 31-38.

Cohen, S. N., A. C. Y. Chang, H. W. Boyer, and R. B. Helling (1973), "Construction of Biologically Functional Bacterial Plasmids in vitro." Proceedings of the National Academy of Sciences of the United States of America, 70, pp. 3240-3244.

Cook, G., E. Pieri, and P. T. Robbins (2004), "The Scientists Think and the Public Feels: Expert Perceptions of the Discourse of GM Food." Discourse \& Society, 15, pp. 433-449.

Vries, R. (2006), “Genetic Engineering and the Integrity of Animals." Journal of Agricultural and Environmental Ethics, 19, pp. 469-493.

Deblonde, M., and P. du Jardin (2005), "Deepening a Precautionary European Policy." Journal of Agricultural and Environmental Ethics, 18, pp. 319-343.

Deckers, J. (2005), “Are Scientists Right and Non-scientists Wrong? Reflections on Discussions of GM." Journal of Agricultural and Environmental Ethics, 18, pp. 451-478.

Devos, Y., D. Reheul, A. Schrijver, F. Cors, and W. Moens (2004), "Management of Herbicide-tolerant Oilseed Rape in Europe: A Case Study on Minimizing Vertical Gene Flow." Environmental Biosafety Research, 3, pp. 135-148.

Devos, Y., D. Reheul, and A. Schrijver (2005), "The Co-existence between Transgenic and Non-transgenic Maize in the European Union: A Focus on Pollen Flow and Cross-fertilization." Environmental Biosafety Research, 4, pp. 71-87.

Devos, Y., D. Reheul, D. De Waele, and L. Van Speybroeck (2006), "The Interplay Between Societal Concerns and the Regulatory Frame on GM Crops in the European Union." Environmental Biosafety Research 5, pp. 127-149.

Devos, Y., D. Reheul, O. Thas, E. M. De Clercq, M. Cougnon, and K. Cordemans (2007), "Implementing Isolation Perimeters around Genetically Modified Maize Fields. Agronomy for Sustainable Development 27, pp. 155-165.

Dornan, C. (1990), "Some Problems in Conceptualizing the Issue of Science and the Media." Critical Studies in Mass Communication, 7, pp. 48-71.

European Commission (2006), Report on the Implementation of National Measures on the Co-existence of Genetically Modified Crops with Conventional and Organic Farming. Retrieved March 19, 2007, from http://europa.eu.int/comm/agriculture/coexistence/index_en.htm.

European Food Safety Authority (2006), "Transparency in Risk Assessment Carried Out by EFSA: Guidance Document on Procedural Aspects." EFSA Journal, 353, pp. 1-16.

Evans, G., and J. Durant (1995), "The Relationship between Knowledge and Attitudes in the Public Understanding of Science in Britain." Public Understanding of Science, 4, pp. 57-74. 
Finucane, M. L., and J. L. Holup (2005), "Psychosocial and Cultural Factors Affecting the Perceived Risk of Genetically Modified Food: An Overview of the Literature." Social Science \& Medicine, 60, pp. 1603-1612.

Fraley, R. T., S. G. Rogers, R. B. Horsch, P. R. Sanders, J. S. Flick, S. P. Adams M. L. Bittner, L. A. Brand, C. L. Fink, J. S. Fry, G. R. Galluppi, S. B. Goldberg, N.L. Hoffmann, and S. C. Woo (1983), "Expression of Bacterial Genes in Plant Cells." Proceedings of the National Academy of Sciences of the United States of America, 80, pp. 4803-4807.

Freudenburg, W. R. (1996), "Risky Thinking: Irrational Fears about Risk and Society." The Annals of the American Academy of Political and Social Science, 545, pp. 44-53.

Frewer, L., J. Lassen, B. Kettlitz, J. Scholderer, V. Beekman, and K. G. Berdal (2004), "Societal Aspects of Genetically Modified Food." Food and Chemical Toxicology, 42, pp. 1181-1193.

Funtowicz, S. O., and J. R. Ravetz (1994), "Uncertainty, Complexity and Postnormal Science." Environmental Toxicology and Chemistry, 13, pp. 1881-1885.

Gamson, W. A., and A. Modigliani (1989), "Media Discourse and Public Opinion on Nuclear Power: A Constructionist Approach." American Journal of Sociology, 95, pp. $1-37$.

Gaskell, G., A. Allansdottir, N. Allum, C. Corchero, C. Fischler, J. Hampel, J. Jackson, N. Kronberger, N. Mejlgaard, G. Revuelta, C. Schreiner, S. Stares, H. Torgersen, and W. Wagner (2006), Europeans and Biotechnology in 2005: Patterns and Trends, Eurobarometer 64.3. Retrieved March 19, 2007, from http:// www.ec.europa.eu/research/press/2006/pdf/pr1906_eb_64_3_final_reportmay2006_en.pdf.

Genus, A., and A. M. Coles (2005), "On Constructive Technology Assessment and Limitations on Public Participation in Technology Assessment." Technology Analysis \& Strategic Management, 17, pp. 433-443.

Gregory, R., J. Flynn, and P. Slovic. (2001), "Technological Stigma," in J. Flynn P. Slovic, and H. Kunreuther (eds.), Risk, Media and Stigma. Understanding Public Challenges to Modern Science and Technology, London/Sterling VA: Earthscan, pp. 3-8.

Gross, A. G. (1994), "The Roles of Rhetoric in the Public Understanding of Science." Public Understanding of Science, 3, pp. 3-23.

Gutteling, J., and O. Wiegman (1996), Exploring Risk Communication. Advances in Natural and Technological Hazards Research, Dordrecht: Kluwer Academic Publishers.

Hagendijk, R., and A. Irwin (2006), "Public Deliberation and Governance: Engaging with Science and Technology in Contemporary Europe." Minerva, 44, pp. 167184.

Haller, S. F., and J. Gerrie (2007), "The Role of Science in Public Policy: Higher Reason, or Reason for Hire?." Journal of Agricultural and Environmental Ethics, 20, pp. 139-165.

Healy, S. (1999), "Extended Peer Communities and the Ascendance of Post-normal Politics.” Futures, 31, pp. 655-669.

Heller, C. (2002), "From Scientific Risk to paysan Savoir-faire: Peasant Expertise in the French and Global Debate Over GM Crops." Science as Culture, 11, pp. 5-37. 
Herrera-Estrella, L., A. Depicker, M. Montagu, and J. Schell (1983), "Expression of Chimaeric Genes Transferred into Plant Cells Using a Ti-plasmid Derived Vector." Nature, 303, pp. 209-213.

Hindmarsh, R., and H. Gottweis (2005), "Recombinant Regulation: The Asilomar Legacy 30 years on." Science as Culture, 14, pp. 299-307.

Horst, M. (2007), "Public Expectations of Gene Therapy: Scientific Futures and Their Performative Effects on Scientific Citizenship." Science, Technology \& Human Values, 32, pp. 150-171.

House of Lords (2000), Science and Society: Third Report of the House of Lords Select Committee on Science and Technology. HMSO, HL Paper 38.

Hughes, S. S. (2001), "Making Dollars Out of DNA. The First Major Patent in Biotechnology and the Commercialization of Molecular Biology, 1974-1980." Isis, 92, pp. 541-575.

Irwin, A. (2006), "The Politics of Talk: Coming to Terms with the 'New' Scientific Governance." Social Studies of Science, 36, pp. 299-320.

Irwin, A., and W. Wyne (1996), Misunderstanding Science? The Public Reconstruction of Science and Technology, Cambridge: Cambridge University Press.

Jasanoff, S. (2003), “Technologies of humility: Citizen Participation in Governing Science." Minerva, 41, pp. 223-244.

Jensen, K. K. (2006), "Conflict Over Risks in Food Production: A Challenge for Democracy." Journal of Agricultural and Environmental Ethics, 19, pp. 269-283.

Jensen, K. K., and P. Sandøe (2002), "Food Safety and Ethics: The Interplay between Science and Values." Journal of Agricultural and Environmental Ethics, 15, pp. 245-253.

Jensen, K. K., C. Gamborg, K. H. Madsen, R. B. Jørgensen, M. KrayervonKrauss, A. P. Folker, and P. Sandøe (2003), "Making the EU 'Risk Window' Transparent: the Normative Foundation of Risk Assessment of GMOs." Environmental Biosafety Research, 3, pp. 161-171.

Johnson, K. L., A. F. Raybould, M. D. Hudson, and G. M. Poppy (2007), "How Does Scientific Risk Assessment of GM Crops Fit within the Wider Risk Analysis?." Trends in Plant Science, 12, pp. 1-5.

Karlsson, M. (2003), "Ethics of Sustainable Development - a Study of Swedish Regulations for Genetically Modified Organisms." Journal of Agricultural and Environmental Ethics, 16, pp. 51-62.

Kasperson, R. E., and J. X. Kasperson (1996), "The Social Amplification and Attenuation of Risk." The Annals of the American Academy of Political and Social Science, 545, pp. 95-105.

Kasperson, R. E., N. Jhaveri, and J. X. Kasperson. (2001), "Stigma and the Social Amplification of Risk: Toward a Framework of Analysis," in J. Flynn, P. Slovic, and H. Kunreuther (eds.), Risk, Media and Stigma. Understanding Public Challenges to Modern Science and Technology, London/Sterling VA: Earthscan, pp. 927.

Krimsky, S (2005), "From Asilomar to Industrial Biotechnology: Risks, Reductionism and Regulation." Science as Culture, 14, pp. 309-323.

Krohn, W., and J. Weyer (1994), "Society as a Laboratory: The Societal Risks of Experimental Research." Science and Public Policy, 21, pp. 173-183.

Lassen, J., and A. Jamison (2006), "Genetic Technologies Meet the Public: The Discourses of Concern." Science, Technology \& Human Values, 31, pp. 8-28. 
Lassen, J., K. H. Madsen, and P. Sandøe (2002), "Ethics and Genetic Engineering Lessons to be Learned from GM Foods." Bioprocess and Biosystems Engineering, 24, pp. 263-271.

Levidow, L. (2001), "Precautionary Uncertainty: Regulating GM Crops in Europe." Social Studies of Science, 31, pp. 842-874.

Levidow, L. (2006), "EU Agbiotech Regulation.” Soziale Technik, 3, pp. 10-12.

Levidow, L., and J. Bijman (2002), "Farm Inputs under Pressure from the European Food Industry." Food Policy, 27, pp. 31-45.

Levidow, L. and K. Boschert (in press), Coexistence or Contradictions? GM Crops Versus Alternative Agricultures in Europe. Geoforum doi: 10.1016/j.geoforum. 2007.01.001.

Levidow, L., and S. Carr (2007), "GM Crops on Trial: Technological Development as a Real-world Experiment." Futures, 39, pp. 408-431.

Levidow, L., and C. Marris (2001), "Science and Governance in Europe: Lessons from the Case of Agricultural Biotechnology." Science and Public Policy, 28, pp. $345-360$.

Levidow, L., S. Carr, and D. Wield (2005), "European Union Regulation of Agribiotechnology: Precautionary Links between Science, Expertise and Policy." Science and Public Policy, 32, pp. 261-276.

Lindsey, N., M. W. Kamara, E. Jelsøe, and A. T. Mortensen (2001), "Changing Frames: The Emergence of Ethics in European Policy on Biotechnology." Notizie di Politeia, XVII, pp. 80-93.

Löfstedt, R., and L. Frewer (1998), Risk and Modern Society, London: Earthscan Reader.

Logan, R. A. (2001), "Science Mass Communication. Its Conceptual History." Science Communication, 23, pp. 135-163.

Madsen, K. H., and P. Sandøe (2005), "Ethical Reflections on Herbicide-resistant Crops." Pest Management Science, 61, pp. 318-325.

Marsden, T., and R. Sonnino. (2005), "Rural Development and Agri-food Governance in Europe: Tracing the Development of Alternatives," in V. Higgins, and G. Lawrence (eds.), Agricultural Governance: Globalization and the New Politics of Regulation, London: Routledge, pp. 50-68.

Marris, C. (2001), "Public Views on GMOs: Deconstructing the Myths." EMBO reports, 2, pp. 545-548.

Maeseele, P. A. (2007), "Science and Technology in a Mediatized and Democratized Society." Journal of Science Communication, 6, pp. 1-10.

Mayer, S., and A. Stirling (2002), "Finding a Precautionary Approach to Technological Developments - Lessons for the Evaluation of GM Crops." Journal of Agricultural and Environmental Ethics, 15, pp. 57-71.

McQuail, D. (2006), "Comparing Media Systems: Three Models of Media and Politics." European Journal of Communication, 20, pp. 266-268.

Mepham, B. (2000), "A Framework for the Ethical Analysis of Novel Foods: The Ethical Matrix." Journal of Agricultural and Environmental Ethics, 12, pp. 165176.

Myhr, A. I., and T. Traavik (2003), "Sustainable Development and Norwegian Genetic Engineering Regulations: Applications, Impacts and Challenges." Journal of Agricultural and Environmental Ethics, 16, pp. 317-335. 
Nielsen, T. H., and S. F. Berg (2001), “Goethe's Homunclus and Shelley's Monster on the Romantic Prototypes of Modern Biotechnology." Notizie di Politeia, XVII, pp. $37-50$.

Nowotny, H. (2003), "Democratising Expertise and Socially Robust Knowledge." Science and Public Policy, 30, pp. 151-156.

Petsko, G. A. (2002), “An Asilomar Moment.” Genome Biology, 3, comment 1014.11014.3.

Power, M., and L. S. McCarty (2006), "Environmental Risk Management Decisionmaking in a Societal Context." Human and Ecological Risk Assessment, 12, pp. 1827.

Savadori, L., S. Savio, E. Nicotra, R. Rumiati, M. Finucane, and P. Slovic (2004), "Expert and Public Perception of Risk from Biotechnology." Risk Analysis, 24, pp. 1289-1299.

Schot, J., and A. Rip (1996), "The Past and Future of Constructive Technology Assessment." Technological Forecasting and Social Change, 54, pp. 251-268.

Schuurman, D., P. A. Maeseele, and H. Verstraeten (2006, May), Biotech, Public Opinion and the Popular Press: Frankenstein's Copycat Soldiers at War? Paper presented at the $9^{\text {th }}$ International Conference on Public Communication of Science \& Technology, Scientific Culture for Global Citizenship, COEX, Seoul.

Shaw, A. (2002), "It Just Goes Against the Grain. Public Understandings of Genetically Modified (GM) Food in the UK." Public Understanding of Science, 11, pp. 273-291.

Siegrist, M. (2000), "The Influence of Trust and Perceptions of Risks and Benefits on the Acceptance of Gene Technology." Risk Analysis, 20, pp. 195-203.

Singer, M., and D. Soll (1973), "Letter from the Members of the Gordon Conference to the Presidents of the National Academy of Sciences and the Institute of Medicine." Science, 181, pp. 1114.

Singer, M., and P. Berg (1976), "Recombinant DNA: NIH Guidelines." Science, 193, pp. 186-188.

Slovic, P. (1987), "Perception of Risk." Science, 236, pp. 280-285.

Slovic, P., M. L. Finucane, E. Peters, and D. G. MacGregor (2004), "Risk as Analysis and Risk as Feeling: Some Thought about Affect, Reason, Risk, and Rationality." Risk Analysis, 24, pp. 311-322.

Streiffer, R., and A. Rubel (2004), "Democratic Principles and Mandatory Labelling of Genetically Modified Food.” Public Affairs Quarterly, 18, pp. 223-248.

Streiffer, R., and T. Hedemann (2005), "The Political Import of Intrinsic Objections to Genetically Engineered Food." Journal of Agricultural and Environmental Ethics, 18, pp. 191-210.

Tiedje, J. M., R. K. Colwell, Y. L. Grossman, R. E. Hodson, R. E. Lenski, R. N. Mack, and P. L. Regal (1989), "The Planned Introduction of Genetically Engineered Organisms: Ecological Considerations and Recommendations." Ecology, 70, pp. 298-315.

Sluijs, J. P. (2007), "Uncertainty and Precaution in Environmental Management: Insights from the UPEM Conference." Environmental Modelling \& Software, 22, pp. 590-598.

Verhoog, H., M. Matze, E. L. Bueren, and T. Baars (2003), "The Role of the Concept of the Natural (Naturalness) in Organic Farming." Journal of Agricultural and Environmental Ethics, 16, pp. 29-49. 
Wandall, B. (2004), "Values in Science and Risk Assessment." Toxicology Letters, 152, pp. 265-272.

Watson, J. D., and J. Tooze (1981), The DNA Story - a Documentary History of Gene Cloning, San Francisco: WH Freeman \& Company.

Welsh, R., and D. Ervin (2006), "Precaution as an Approach to Technology Development: The Case of Transgenic Crops." Science Technology \& Human Values, 31, pp. 153-72.

Welsh, R., and L. Glenna (2006), "Considering the Role of the University in Conducting Research on Agri-biotechnologies." Social Studies of Science, 36, pp. 929 942.

Wilsdon, W., and J. Stilgoe (2005), The Public Value of Science, London: Demos.

Winickoff, D., S. Jasanoff, L. Busch, R. Grove-White, and B. Wynne (2005), "Adjudicating the GM Food Wars: Science, Risk, and Democracy in World Trade Law." The Yale Journal of International Law, 30, pp. 81-123.

Wright, S. (1986), "Recombinant DNA Technology and its Social Transformation, 1972-1982." Osiris 2nd Series, 2, pp. 303-360.

Wynne, B. (1992), "Misunderstood Misunderstanding: Social Identities and Public Uptake of Science." Public Understanding of Science, 1, pp. 281-304.

Wynne, B.. (1995), "Public Understanding of Science," in S. Jasanoff, G. E. Markle, J. C. Petersen, and T. Pinch (eds.), Handbook of Science and Technology Studies, Thousand Oakes/London/New Delhi: Sage, pp. 361-388.

Wynne, B. (2001), "Expert Discourses of Risks and Ethics on Genetically Manipulated Organisms: The Weaving of Public Alienation." Notizie di Politeia, XVII, pp. $51-76$. 